\title{
Responses of the antioxidant defences of Labeo rohita exposed to Basic violet-1 (BV-1)
}

\author{
Satinder Kaur \\ P.G. Department of Zoology, Khalsa College Amritsar, Amritsar-143005 (Punjab), India \\ Kirandeep Kaur \\ P.G. Department of Zoology, Khalsa College Amritsar, Amritsar-143005 (Punjab), India \\ Arvinder Kaur* \\ Department of Zoology, Guru Nanak Dev University, Amritsar-143005 (Punjab), India \\ ${ }^{*}$ Corresponding author. E-mail: kaurarvinder1012@gmail.com
}

\begin{abstract}
Present study envisaged evaluating the effect of Basic violet-1 (BV-1, Cl No. 42535), a widely used azo dye in dyeing and textile industries, on antioxidant enzymes of Labeo rohita fingerlings $(7.6-11.3 \mathrm{~cm}$ length and $16.1-26.7 \mathrm{~g}$ weight). Antioxidant enzymes such as acetylcholinesterase (AChE), succinate dehydrogenase $(\mathrm{SDH})$, aspartate transaminase (AST) and alanine transaminase (ALT) were estimated in liver, kidney, gill, muscle and brain of the fish as markers for the stress of BV-1. After $96 \mathrm{~h}$, the fish were kept for a recovery period of 30 days and activity of enzymes was determined at 15 day intervals. Significant dose dependent increase over control in the activity of AST (79.69\%) and ALT $(50.07 \%)$ was observed in all the tissues while a significant decrease over control was observed in AChE (717.43\%) and SDH (173.07\%) activity in all the tissues. Alterations in the activity of enzymes could probably be due to a defense against oxidative damage caused by the dye and prolonged effect till the end of the recovery period could be a metabolic adaptation of the fish to the stress of the present dye. The results indicate that the dye is very toxic to $L$. rohita as there was a marked change in the activity of selected enzymes in the exposed fish and the effect prolonged till the end of recovery period. So these enzymes in the selected tissues can be considered as best biomarker to determine toxicity of even very low doses of the azo dye BV-1 in fish.
\end{abstract}

Keywords: Antioxidant enzymes, Azo dye, Basic violet-1, Detoxification, Liver, L. rohita.

\section{INTRODUCTION}

Anthropogenic activities are responsible for increasing levels of pollutants in the aquatic environment all over the world (Zaharia and Suteu, 2012). Discharge of wastewater loaded with azo dyes from textile and food industries has adversely affected water bodies. Azo dyes pose threat to aquatic organisms as well as terrestrial animals. Approximately, 10,000 different dyes are used in industries, and over $7 \times 10^{5}$ tons of synthetic dyes are produced annually worldwide. It is estimated that worldwide these industries discharge around 280,000 tons of dyes into the environment every year (Kumar et al., 2009). During dyeing process, a substantial amount of azo dye (10-15\%) is lost in wastewater (Hassaan and El Nemr, 2017). At the same time even a very small amount of dye in water (10-50 $\mathrm{mg} / \mathrm{l})$ affects the transparency and gas solubility of water (Banat et al., 1996).

Molecular and cellular biomarkers measured in aquatic organisms respond rapidly to the stress caused by environmental contaminants, and can be used to assess the health status of organisms

\section{Article Info}

DOI:10.31018/jans.v10i4.1911 Received: October 2, 2018

Revised: November 8, 2018

Accepted: November 25, 2018

\section{How to Cite}

Kaur, S. et al. (2018).

Responses of the antioxidant defences of Labeo rohita exposed to Basic violet-1 (BV-1). Journal of Applied and Natural Science, 10(4): 1248-1253 versible damage occurs at a higher level of biological organization. Bioaccumulation of toxic substances triggers redox reactions generating free radicals, especially free oxygen radicals, but also other reactive oxygen species (ROS) are produced, that induce biochemical alterations in fish tissues (Woo et al., 2006). To counteract the toxic effects of ROS, aerobic organisms use both enzymatic and non-enzymatic antioxidants to scavenge the free radicals. However, when ROS generation exceeds the capacity of the cellular antioxidants, it will cause oxidative stress and oxidative damage (Morena et al., 2005). Therefore, oxidation-related biomarkers, including oxidative stress indices and antioxidant parameters, are used in environmental risk assessment (Li et al., 2010). Changes in the levels of antioxidants have been proposed as biomarkers of contaminant-mediated prooxidant challenge in a variety of marine organisms, including fish (Regoli et al., 2002). Defense systems that prevent the formation of ROS, include the antioxidant enzymes such as succinate dehydrogenase $(\mathrm{SDH})$, aspartate transaminase 
(AST) and alanine transaminase (ALT). Complex mixtures of pollutants cause deleterious effects on the quality of water as well as on fish and other aquatic organisms. Fish acts as an important indicator of water quality under such conditions as it remains in direct contact with water for food and oxygen and is highly sensitive to any change in its environment (Kaur et al., 2013). Fish adjusts its metabolism to adapt to the altered environment, therefore biochemical markers such as enzymes, proteins and amino acids of fish have been widely used in the studies related to toxicology, ecotoxicology and pharmacology.

Fish, Labeo rohita, are found abundantly in the rivers of India and are cultivated at a large scale in Punjab. Levels of antioxidant enzymes, acetylcholinesterase (AChE), succinate dehydrogenase $(\mathrm{SDH})$, aspartate transaminase (AST) and alanine transaminase (ALT) were estimated in liver, kidney, gill, muscle and brain after 96h of exposure as an indicator of the stress of the selected lethal doses of the dye. Little work has been done on the effect of the azo dyes on antioxidant enzymes of fish. In the present study, acute toxic potential of Basic violet-1 (BV-1) was evaluated in L. rohita. It will help to explore these biomarkers in the fish as an indicator of toxicity of acute doses of BV-1.

\section{MATERIALS AND METHODS}

Chemicals: All AR grade chemicals used for the present study were purchased from SRL, SigmaAldrich and Himedia. Azo dye, BV-1 (Cl: 42535) was purchased from the local market, Amritsar, Punjab, India.

Animal care: Fingerlings of $L$. rohita $(7.6-11.3$ $\mathrm{cm}$ length and $16.1-26.7 \mathrm{~g}$ weight) were collected from the ponds of Government Fish Farm, Rajasansi, Amritsar and subjected to an acclimation period of three weeks in plastic pools of $200 \mathrm{~L}$ capacity in the laboratory. Fish were fed on Toya floating pellets during acclimation as well as experimental period except for $24 \mathrm{~h}$ preceeding exposure and during the bioassay. Tap water after dechlorination was used as diluent and control, test water was changed every day.

$\mathrm{pH}$, Temperature and Electrical conductivity of water were recorded by using soil and water analysis kit (Decible-DB-1203) manufactured by Decible, India Ltd. TDS, TS, DO, free $\mathrm{CO}_{2}$ and total alkalinity were determined according to APHA (1998). Average of the physico-chemical parameters of the water was: $\mathrm{pH}-7.3$, temperature- $27^{\circ} \mathrm{C}$, electrical conductivity- $570 \mu \mathrm{mhos} / \mathrm{cm}$, total dissolved solids (TDS)- $0.1 \mathrm{~g} / \mathrm{l}$, total solids (TS)- 0.6 $\mathrm{g} / \mathrm{l}$, total suspended solids (TSS)- $0.5 \mathrm{~g} / \mathrm{l}$, dissolved oxygen (DO)- $5.2 \mathrm{mg} / \mathrm{l}$, free $\mathrm{CO}_{2}-8.5 \mathrm{mg} / \mathrm{l}$, total alkalinity- $332.6 \mathrm{mg} / \mathrm{l}$.

Experiment design: 10 fishes were exposed in each concentration in duplicate to $0,0.2\left(\mathrm{LC}_{20}\right)$, $0.4\left(\mathrm{LC}_{40}\right), 0.6\left(\mathrm{LC}_{60}\right), 0.8\left(\mathrm{LC}_{80}\right)$ and $1\left(\mathrm{LC}_{100}\right) \mathrm{mg} /$
I of BV-1 for $96 \mathrm{~h}$ and alive fish from each concentration were kept for 30 days in tap water for recovering from the stress of the dye.

Liver, kidney, gill, muscle and brain of the fish after exposure (96h) were dissected out, kept in respective buffers, dried, weighed and homogenized in cold buffer. Ice was kept around the tissues to avoid heating and denaturing of the enzymes. The homogenate was centrifuged at $10,000 \times \mathrm{g}$ for $45 \mathrm{~min}$ at $+4^{\circ} \mathrm{C}$. Supernatant was collected and antioxidant enzymes were estimated with Systronic dual beam spectrophotometerGenesis 10UV.

Acetylcholinesterase (AChE) was estimated according to the method given by Ellman et al. (1961) and absorbance was measured at $412 \mathrm{~nm}$. The specific activity was reported as $\mathrm{nM} / \mathrm{min} / \mathrm{mg}$ protein.

Succinate dehydrogenase (SDH) was assayed by the method of King (1967). The decrease in absorbance at $420 \mathrm{~nm}$ was measured corresponding to the reduction of ferricyanide. The specific activity was calculated as $\mathrm{mM} / \mathrm{min} / \mathrm{mg}$ protein.

The method given by Wilkinson et al. (1972) was used for measuring the activity of Aspartate transaminase (AST) and Alanine transaminase (ALT). The decrease in absorbance was recorded at 340 $\mathrm{nm}$. The specific activity was calculated as U/min/ mg protein.

Protein measurement: Concentration of protein in the extract was measured by the method of Lowry et al. (1951) with Bovine serum albumin as standard.

Statistical analysis: Data were subjected to ANOVA for finding out the differences in the activity of enzyme before and after exposure and within the groups. Tukey test was used for finding differences among the enzyme activity of the fish. The biochemical results are reported as Mean \pm S.E. The differences were regarded as statistically significant when $\mathrm{P}<0.001$ to $\mathrm{P}<0.05$.

\section{RESULTS}

On exposure to the dye the fish became restless, tried to jump out of the water and the response was dose-dependent, gradually they stopped swimming and remained static in a corner of the aquarium. Intermitently fish swim unsteadily with jerky movements gulping intensity increased and fish turned upside down before mortality. Mucus secretion increased in the exposed fish and dead fish had a thick coat of mucus on the body and gills. Color of the body, gills and viscera became bluish violet on exposure to higher doses of BV-1. Exposure to the dye also brought a decline in feeding intensity during recovery period.

Values for enzyme activity after $96 \mathrm{~h}$ exposure and on the $15^{\text {th }}$ and $30^{\text {th }}$ day of recovery period are depicted in Fig. 1-4. Enough fish was not available, so the observations could not be recorded for 
Kaur, S. et al. / J. Appl. \& Nat. Sci. 10 (4): 1248-1253 (2018)

A

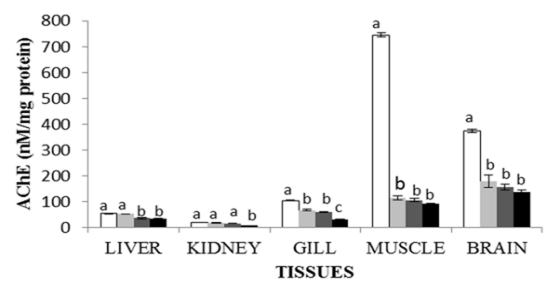

ICONTROL

$=0.2 \mathrm{mg} / \mathrm{l}$

$=0.4 \mathrm{mg} / \mathrm{l}$

- $0.6 \mathrm{mg} / \mathrm{l}$

B
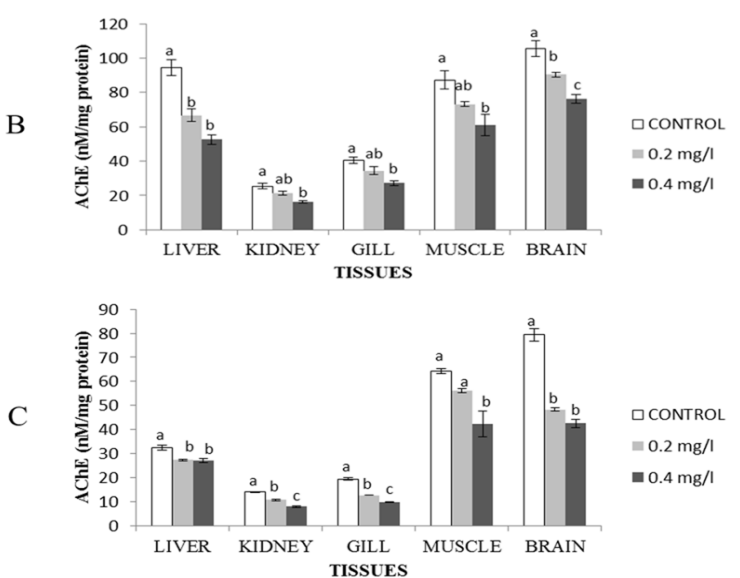

Fig. 1. Effect of $B V-1$ on the activity of AChE (nM) $\mathrm{min} / \mathrm{mg}$ protein, Mean \pm S.E) after $96 \mathrm{~h}$ exposure (A), on $15^{\text {th }}$ day $(B)$ and on $30^{\text {th }}$ day of recovery period (C). Values with different superscript ( $a, b, c$ and $d$ ) are significantly different at $P<0.05$.

A
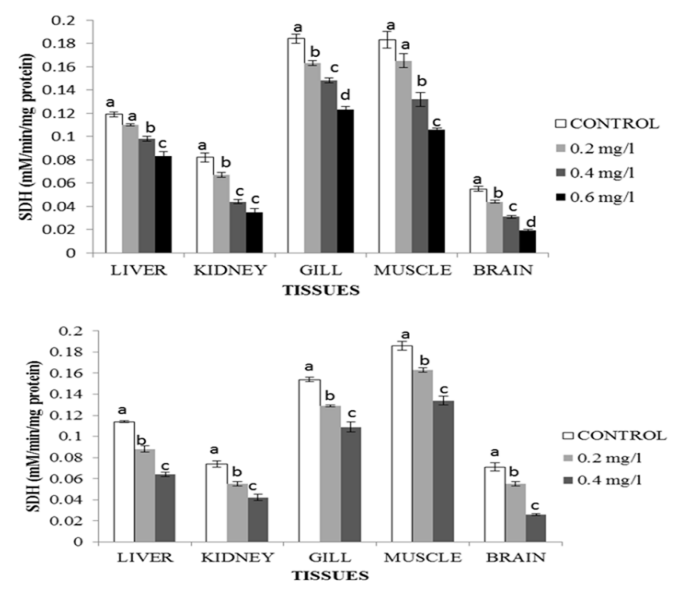

$\mathrm{C}$

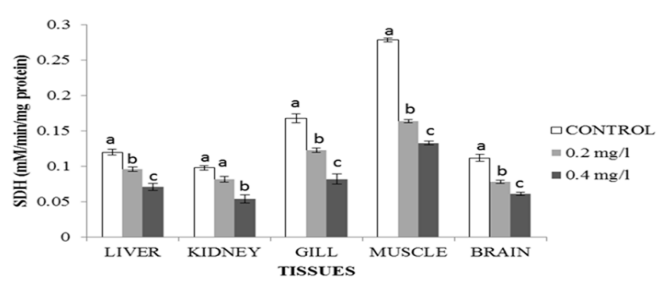

Fig. 2. Effect of $B V-1$ on the activity of $S D H(\mathrm{mM} / \mathrm{min}$ / $m g$ protein, Mean \pm S.E) after $96 \mathrm{~h}$ exposure $(A)$, on $15^{\text {th }}$ day $(B)$ and $30^{\text {th }}$ day of recovery period (C). Values with different superscript $(a, b, c$ and $d)$ are significantly different at $P<0.05$.

$0.8 \mathrm{mg} / \mathrm{l}$ concentrations after $96 \mathrm{~h}$ exposure and $0.6 \mathrm{mg} / \mathrm{l}$ concentration on the $15^{\text {th }}$ and $30^{\text {th }}$ day of recovery period.
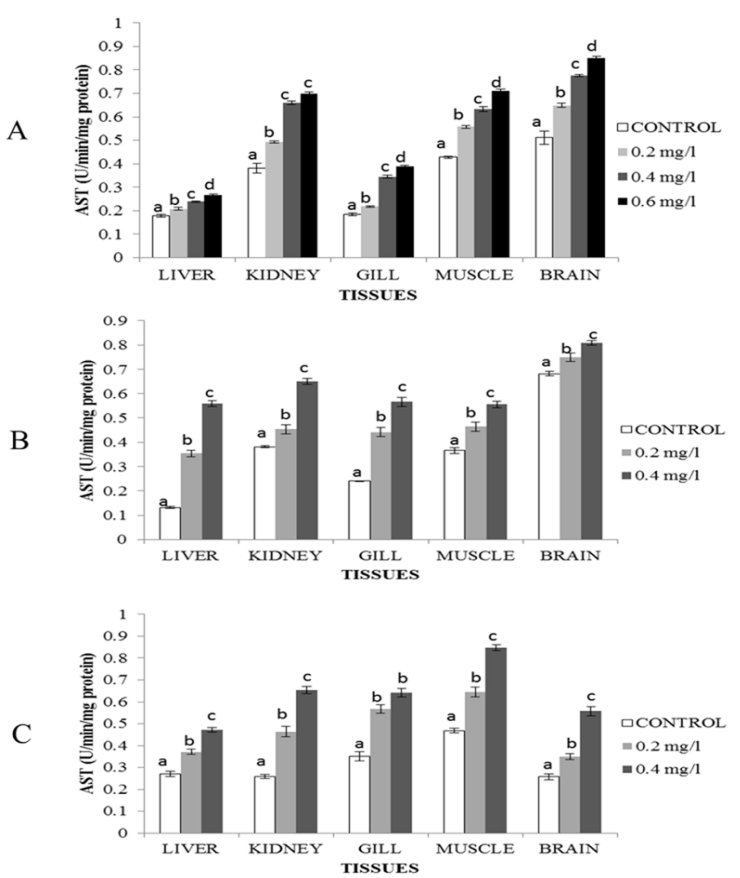

Fig. 3. Effect of BV-1 on the activity of AST (U/min/ $m g$ protein, Mean \pm S.E) after $96 \mathrm{~h}$ exposure $(A)$, on $15^{\text {th }}$ day $(B)$ and $30^{\text {th }}$ day of recovery period (C). Values with different superscript ( $a, b, c$ and d) are significantly different at $P<0.05$.

A

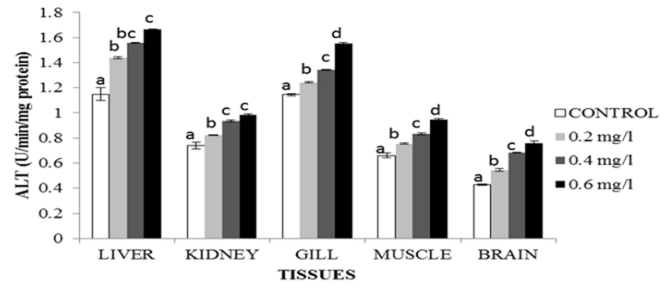

B
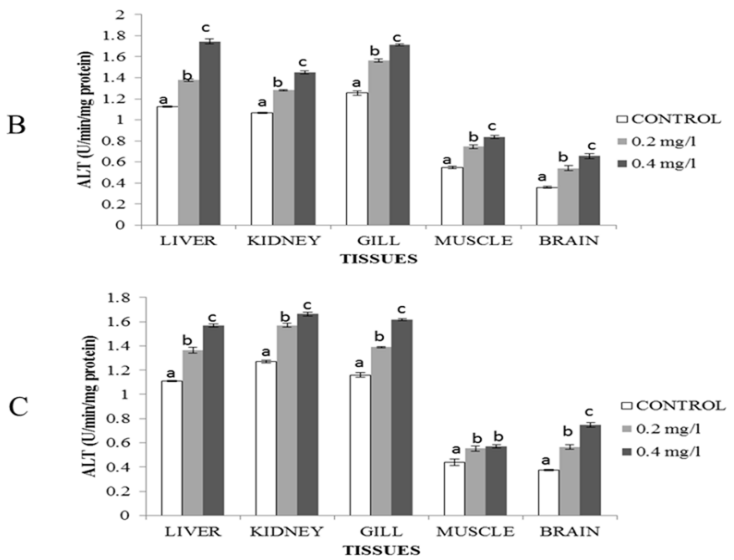

Fig. 4. Effect of $B V-1$ on the activity of $A L T(U / \mathrm{min} /$ $m g$ protein, Mean \pm S.E) after $96 \mathrm{~h}$ exposure (A), on $15^{\text {th }}$ day $(B)$ and $30^{\text {th }}$ day of recovery period $(C)$. Values with different superscript $(a, b, c$ and $d)$ are significantly different at $P<0.05$.

The activity of AChE decreased significantly over control $(p<0.05)$ in all the tissues in a dose dependent manner after $96 \mathrm{~h}$ exposure (Fig. 1A) as 
well as on the $15^{\text {th }}$ and $30^{\text {th }}$ day of recovery period (Fig. 1B and $1 \mathrm{C}$, respectively). The highest decrease in AChE activity was noticed in muscle (717.43\%), liver $(79.47 \%)$ and gill $(97.96 \%)$ after $96 \mathrm{~h}$ exposure, on the $15^{\text {th }}$ and $30^{\text {th }}$ day of recovery period, respectively.

The activity of SDH decreased dose dependently over control $(P<0.001)$ in all the tissues after 96h exposure to the dye and on $15^{\text {th }}$ and $30^{\text {th }}$ day of recovery period (Fig. 2A, 2B, 2C). The maximum decrease in SDH activity over control was observed in muscle $(109.77 \%, 72.64 \%)$ and brain $(173.07 \%)$ at $0.6 \mathrm{mg} / \mathrm{l}$ on the $30^{\text {th }}$ day of recovery period and after $96 \mathrm{~h}$, on the $15^{\text {th }}$ day of recovery period, respectively.

The activity of AST increased over control $(\mathrm{P}<0.001)$ in all the tissues after $96 \mathrm{~h}$ as well as on the $15^{\text {th }}$ and $30^{\text {th }}$ day of recovery period. Maximum increase was observed in liver $(79.69 \%)$, kidney $(60.40 \%)$ and gill $(52.58 \%)$ on $15^{\text {th }}$ day, $30^{\text {th }}$ day and after $96 \mathrm{~h}$ exposure, respectively (Fig. 3A, 3B, 3C).

A dose dependent increase over control $(P<0.01)$ in ALT activity was observed in all the tissues after $96 \mathrm{~h}$ exposure as well as on the $15^{\text {th }}$ and $30^{\text {th }}$ day of recovery period. Maximum increase over control was noticed in brain $(43.89 \%, 45.19 \%$ and $50.07 \%$ ) on these durations (Fig. 4A, 4B, 4C).

\section{DISCUSSION}

Cellular oxidative stress is established when the pro-oxidant forces overwhelm the antioxidant defences. These antioxidant defences comprise enzymatic and non-enzymatic mechanisms. These systems can prevent the formation of oxyradicals or intercept oxidative propagation reactions promoted by the oxyradicals once formed (Bainy et al., 1996). Since many environmental contaminants exert toxic effects related to oxidative stress, antioxidant enzymes activities are being studied as potential biomarkers in environmental risk assessment programs (Vander Oost et al., 2003). In the present study, on exposure to Basic violet-1 (BV-1), biochemical responses observed in liver, kidney, gill, muscle and brain of L. rohita exposed for $96 \mathrm{~h}$ indicated that the toxicity of the dye prolonged for a long time as the fish was not able to recover from the stress even 30 days after the exposure.

A dose and duration dependent increase in bluish violet colour on the body, gills and viscera of the exposed fish indicates absorption/adsorption of present dye by the test fish. Only a slight change in the intensity of bluish violet color from the tissues till the end of the recovery period hints towards strong affinity of the dye for the tissues of the fish. Several dyes have been reported to have high affinity for the tissues of fish (Tonogai et al., 1979, 1980).

AChE is a serine hydrolase whose primary role is to hydrolyze and modulates the amount of neurotransmitter acetylcholine in cholinergic synapses (O' Brien 1967) and it is also concerned with the ionic content (Vander Kloot, 1956). Many workers have reported that dyes and their derivatives are complex inhibitors of AChE (Mansour et al., 2010). The inhibition of AChE and elevation of Ach content may be due to the decreased ionic composition in the tissues of $L$. rohita (David et al., 2009). Malla Reddy et al. (1992) suggested that the inhibition of AChE activity with a concomitant increase in acetylcholine (Ach) content in the tissues is an implication of greater disruption to the integretory activity of the central nervous system. Damage to the central nervous system might have caused uncontrolled hormonal release and the toll of an animal may be possible by the degeneration of many biochemical and physiological functions (Corbett, 1974). Inhibition of AChE in fish was accompanied by an increase in acetylcholine levels that can be dangerous since it will impact feeding capability, swimming activity, identification, avoidance of predators and spatial orientation of the species (Uner et al., 2006).

$\mathrm{SDH}$ is an exclusively mitochondrial marker enzyme located in the mitochondrial inner membrane, is part of both the TCA cycle and respiratory electron transfer chain (Rutter et al., 2010). SDH activity decreased in Spiralothelphusa hydrodroma exposed to textile dye industry effluent (Sekar et al., 2008) and in Labeo rohita exposed to AB-1 dye (Kaur and Kaur, 2015). Decrease in $\mathrm{SDH}$ activity in the tissues of fish has also been reported on exposure to other pollutants like quinolphos and zinc (David et al., 2010; Zheng et al., 2011). Decline in the SDH activity in the current study may be due to an impairment of aerobic respiration. It is pointed out by Tripathi and Shasmal (2011) that utilization of lactate aerobically by the tissues was impaired on exposure of the fish to quinolphos.

Transaminases are mitochondrial and cytosolic enzymes, involved in the catabolism of amino acids and an increase in transaminase activity could either be due to their possible leakage from the cytosol across damaged plasma membrane into the general blood circulation or increase in their synthesis as a result of the organ dysfunction (Vasanth et al., 2012). Amin et al. (2010) and Himri et al. (2011) observed a significant increase in AST and ALT activities in Tartrazine treated rats. A significant increase in AST and ALT activities has also been observed in Clarias lazera exposed to dyestuff and chemical wastewater and $L$. rohita exposed to anthracene by Abdel-Moneim et al. (2008) and Vasanth et al. (2012), respectively. Increase in the activity of transaminases may be due to either increased operation of transamination or increased synthesis of amino acids from one of sources like glucose during exposure (Tilak 
et al., 2005). In present study significant dose dependent decrease over control in AChE and SDH activity while a significant dose dependent increase over control in AST and ALT activity of all the tissues of the dye exposed fish till the end of the recovery period clearly indicates that such fish will be at a greater risk if there is a slight change in their environment in future.

\section{Conclusion}

Fish is a rich source of protein but contaminated fish is a direct threat for man. At levels safe for survival pollutants cause changes in the proteins and DNA of the organisms. The changes in the antioxidant enzymes can be used as biomarkers of toxicity in the absence of mortality. The present study strongly suggests that exposure of BV-1 caused a generalized oxidative stress and damage in all the tissues of $L$. rohita and revealed an organ specific antioxidant response involving a differential modulation of the enzyme activities. AChE was affected more (change over control in all the tissues) and maximum effect was observed in liver. The information presented in this study will be helpful in fully understanding the mechanism of BV-1 toxicity in fish. This study will help in determining the consequences of direct as well as indirect exposure of man to azo dyes as the fish respond to toxins in a manner similar to higher vertebrates and form an important link in the food chain of man.

\section{ACKNOWLEDGEMENTS}

Financial support from University with potential for Excellence (UPE), University Grants Commission (UGC), New Delhi, India is greatly acknowledged.

\section{REFERENCES}

1. Abdel-Moneim, A.M., Abou-Shabana, N.M., Khadre, S.E.M. and Abdel-Kader, H.H. (2008). Physiological and histopathological effects in Catfish (Clarias lazera) exposed to dyestuff and chemical wastewater. International Journal of Zoological Research, 4(4), 189-202. DOI: 10.3923/ijzr.2008.189.202

2. Amin, K.A., Hameid, II H.A. and Elsttar, A.H.A. (2010). Effect of food azo dyes Tartrazine and carmoisine on biochemical parameters related to renal, hepatic function and oxidative stress biomarkers in young male rats. Food and Chemical Toxicology, 48, 2994-2999. doi: 10.1016/j.fct.2010.07.039.

3. APHA. (1998). American Standard Methods for the Examination of Water and Wastewater. 20th Edition. American Publication of Health Association, Wahington, DC: 2005-2605.

4. Bainy, A.C.D., Saito, E., Carvalho, P.S.M. and Junqueira, V.B.C. (1996). Oxidative stress in gill, erythrocytes, liver and kidney of Nile tilapia (Oreochromis niloticus) from a polluted site. Aquatic Toxicology, 34, 151-162. https://doi.org/10.1016/0166-445X(95) 00036-4

5. Banat, I.M., Nigam, P., Singh D. and Marchant, R. (1996) Microbial decolorization of textile-dye contain- ing effluents - a review. Bioresource Technology, 58, 217-227. https://doi.org/10.1016/S0960-8524(96) 00113-7

6. Corbett, J.R. (1974). The biochemical mode of action of pesticides. New York: Academic press.

7. David, M., Patil, V.K., Chebbi, S.G., Marigoudar, S.R., Chitturagi, J.B. and Halappa, R. (2009). Gasliquid chromatography for fenvalerate residue analysis: In vivo alterations in the acetylcholinesterase activity and acetylcholine in different tissues of the fish, Labeo rohita (Hamilton). Toxicology Mechanisms and Methods, 19(6-7), 410-415. doi: 10.1080/15376510903089565.

8. David, M., Ramesh, H., Patil, V.K., Marigoudar, S.R. and Chebbi, S.G. (2010). Sodium cyanide-induced modulations in the activities of some oxidative enzymes and metabolites in the fingerlings of Cyprinus carpio (Linnaeus).Toxicology and Environmental Chemistry, 92(10), 1841-1849. DOI: 10.1080/02772248.2010.498374

9. Ellman, G. L., Courtney, K.D., Andres, V. and Featherstone, R.M. (1961). A new and rapid colorimetric determination of acetylcholinesterase activity. Biochemical Pharmacology, 7, 88-95. https:// doi.org/10.1016/0006-2952(61)90145-9

10.Hassaan, M.A. and EI Nemr, A. (2017). Health and Environmental Impacts of Dyes: Mini Review. American Journal of Environmental Science and Engineering, 1(3), 64-67.

11.Himri, I., Bellahcen, S., Souna, F., Belmekki, F., Aziz, M., Bnouham, M., Zoheir, J., Berkia, Z., Mekhfi, H. and Saalaoui, E. (2011). A 90 day oral toxicity study of tartrazine, a synthetic food dye, in wistar rats. International Journal of Pharmacy and Pharmaceutical Sciences, 3(3), 159-169.

12.Kaur, H., Kalotra, R., Walia, G.K. and Handa, D. (2013). Dyeing industry effluent induced behavioral and morphological changes in the fish, Cirrhinus mrigala. International Journal of Zoological Research, 3(3), 13-20.

13.Kaur, S. and Kaur, A. (2015). Variability in antioxidant/detoxification enzymes of Labeo rohita exposed to an azo dye, Acid black (AB). Comparative Biochemistry and Physiology Part C, 167, 108-116. doi: 10.1016/j.cbpc.2014.06.009.

14.King, T.E. (1967). Preparation of succinate dehydrogenase and reconstitution of succinate oxidase. In: Methods in Enzymology. (Eds. R.W. Estabrook and M.E. Pullman). Academic press, N.Y. 10, pp. 322332. https://doi.org/10.1016/0076-6879(67)10061-X

15.Kumar, K., Dastidar, M.G. and Sreekrishnan, T.R. (2009). Effect of process parameters on aerobic decolourization of reactive Azo dye using mixed culture. International Journal of Biological, Biomolecular, Agricultural, Food and Biotechnological Engineering, 3 (10), 525-528.

16.Li, Z.H., Zlabek, V., Velisek, J., Grabic, R., Machova, J. and Randak, T. (2010). Modulation of antioxidant defense system in brain of rainbow trout (Oncorhynchus mykiss) after chronic carbamazepine treatment. Comparative Biochemistry Physiology Part C, 151, 137-141. doi: 10.1016/j.cbpc.2009.09.006.

17.Lowry, O.H., Rosebrough, N. J., Farr, A.L. and Randall, R.J. (1951). Protein measurement with folin phenol reagent. Journal of Biochemistry, 193, 265-275.

18.Malla Reddy, P., Philip, H.G. and Bashamohideen, M. (1992). Regulation of AChE system of freshwater 
fish, Cyprinus carpio under fenvalerate toxicity. Bulletin of Environmental Contamination and Toxicology, 48:18-22

19.Mansour, H.B., Ayed-Ajmi, Y., Mosrati, R., Corroler, D., Ghedira, K., Barillier, D. and Chekir-Ghedira, L. (2010). Acid violet 7 and its biodegradation products induce chromosome aberrations, lipid peroxidation, and cholinesterase inhibition in mouse bone marrow. Environmental Science and Pollution Research, 17:1371-1378.

20.Morena, I., Pichardo, S., Jos, A., Gomez-Amores, L., Mate, A., Vazquez, C.M. and Camean, A.M. (2005). Antioxidant enzyme activity and lipid peroxidation in liver and kidney of rats exposed to microcystin-LR administered intraperitoneally. Toxicon, 45, 395-402.

21.O' Brien, R.D. (1967). Insecticides action and metabolism. New York: Academic press.

22.Regoli, F., Pellegrini, D., Winston, G.W., Gorbi, S., Giuliani, S., Virno-Lamberti, C. and Bompadre, S. (2002). Application of biomarkers for assessing the biological impact of dredged materials in the Mediterranean: the relationship between antioxidant responses and susceptibility to oxidative stress in the red mullet (Mullus barbatus). Marine Pollution Bulletin, 44, 912-922. https://doi.org/10.1016/S0025-326X (02)00120-0

23.Rutter, J., Winge, D.R. and Schiffman, J.D. (2010). Succinate dehydrogenase- assembly, regulation and role in human disease. Mitochondrion, 10, 393-401. doi: 10.1016/j.mito.2010.03.001.

24.Sekar, P., Hariprasad, S. and Deccaraman, M. (2008). Impact of Textile Dye Industry Effluent on the Neurosecretory Cells in Fresh Water Female Crab Spiralothelphusa hydrodroma (Herbst). Journal of Applied Sciences Research, 4(11), 1526-1533.

25.Tilak, K.S., Veeraiah, K. and Rao, D.K. (2005). Biochemical changes induced by Chlorpyrifos, an organophosphate compound in sublethal concentrations to the freshwater fish Catla catla, Labeo rohita and Cirrhinus mrigala. Journal of Environmental Biology, 26 (2), 341-347.

26.Tonogai, Y., Ito, Y., Iwaida, M., Tati, M., Ose, Y. and Hori, M. (1979). Studies on the toxicity of coal-tar dyes II. The Journal of Toxicological Sciences, 4(3), 211-219.

27.Tonogai, Y., Ito, Y., Iwaida, M., Tati, M., Ose, Y. and Hori, M. (1980). Studies on the toxicity of coal-tar dyes III. The Journal of Toxicological Sciences, 5(1), 23-33.
28.Tripathi, G. and Shasmal, J. (2011). Concentration related responses of chlorpyriphos in antioxidant, anaerobic and protein synthesizing machinery of the freshwater fish, Heteropneustes fossilis. Pesticide Biochemistry and Physiology, 99, 215-220. https:// doi.org/10.1016/j.pestbp.2010.12.006

29.Uner, N., Oruc, E.O., Sevgiler, Y., Sahin, N. Durmaz, H. and Usta, D. (2006). Effects of diazinon on acetylcholinesterase activity and lipid peroxidation in the brain of Oreochromis niloticus. Environmental Toxicology and Pharmacology, 21, 241-245. doi: 10.1016/j.etap.2005.08.007.

30.Vander Kloot, G.W. (1956). Cholinesterase and sodium transport by frog muscle. Nature 178,366 . https:// doi.org/10.1038/178366a0

31.Vander oost, R., Beyer, J. and Vermeulen, P.E. (2003). Fish bioaccumulation and biomarkers in enviormental risk assessment: a review. Environmental Toxicology and Pharmacology, 13, 57-149.

32.Vasanth, S., Ganesh, A., Vijayakumar, T.S., Karthikeyeni, S., Manimegalai, M. and Subramanian, P. (2012). Assessment of anthracene on hepatic and antioxidant enzyme activities in Labeo rohita (Hamilton, 1822). International Journal of Pharmacy and Life Science, 3(5), 1696-1704.

33.Wilkinson, J.H., Baron, D.N., Moss, D.W. and Walker, P.G. (1972). Standardization of clinical enzyme assays: a reference method for aspartate and alanine transaminase. Journal of Clinical Pathology, 25, 940944.

34.Woo, S.P.S., Liu, W.H., Au, D.W.T., Anderson, D.M. and Wu, R.S.S. (2006). Antioxidant responses and lipid peroxidation in gills and erythrocytes of fish (Rhabdosargus sarba) upon exposure to Chattonella marina and hydrogen peroxide: implications on the cause of fish kills. Journal of Experimental Marine Biology and Ecology, 336, 230-241.

35.Zaharia, C. and Suteu, D. (2012). Textile organic dyes - Characteristics, polluting effects and separation/elimination procedures from industrial effluents A critical overview. In: Tomasz, P. (ed). Organic Pollutants Ten Years After the Stockholm Convention Environmental and Analytical Update. pp. 55-86. InTech, Europe.

36.Zheng, J.L., Luo, Z., Chen, Q.L., Liu, X., Liu, C.X., Zhao, Y.H. and Gong, Y. (2011). Effect of waterborne zinc exposure on metal accumulation, enzymatic activities and histology of Synechogobius hasta. Ecotoxicology and Environmental Safety, 74:1864-1873. 